\title{
HE INVISIBLE LANDSCAPE: SUBSOIL, ENVIRONMENT AND THE ITALIAN LEGISLATION ON THE CULTURAL HERITAGE
}

\author{
Laura Domanico \\ École Pratique des Hautes Études, Sorbonne, Paris
}

\begin{abstract}
The study examines the Italian legislation on the cultural heritage and the environment, and points out the cultural gaps from the point of view of the definition and comprehension of these matters; and the delays surrounding the management of the cultural heritage in the territory. While theoretical debate on the environment in Italy has received a strong impulse in recent years, the cultural heritage continues to be governed by generally outdated laws of an essentially restrictive and punitive nature. The environment and cultural heritage are also seen by the Italian legislation as two separate entities, with negative consequences at the level of the protection, safeguarding and evaluation of the heritage. The study also puts forward a unified, dynamic view of the human environment (the interaction between human beings and the environment), which includes both the visible and invisible landscapes, the latter existing concealed beneath the surface. The proposed concept of the subsoil is that of a structured universe, in whose understanding and interpretation archaeology plays a determining role. By protecting and safeguarding only what 'we can see', i.e. the environmental and historic landscape above the soil, the law forgets that this is nothing other than the product of a series of partial landscapes fossilized and stratified in the course of time. By seeking out a new definition of the human environment, the study advances a conception that takes into account continuing transformations while not excluding an intuitive and emotional approach.
\end{abstract}

Keywords: cultural heritage, environment, Italian legislation, soil, subsoil

\section{INTRODUCTION}

Over the last few decades, the theoretical debate on archaeology has placed particular emphasis on the definition of the discipline as a science, and on the perfecting of its methods of research, analysis and data interpretation. While approaches differ, one common strain we can see in the vast bibliography published is a movement away from the traditional conception of archaeology as the simple description and reconstruction of the past. What we are interested in now is how, where, when 
and why ancient communities existed. The central point of our concern is therefore that of explaining changes (Renfrew and Bahn 1996). Regarded in this sense, archaeology therefore appears to have moved beyond its traditional historic-artistic vision of the past and the wholly technical and mathematical context within which it was confined, to emerge as a complete science capable of investigating the history of human beings and their interaction with their surroundings. Originally a static discipline, it has now become a dynamic science, with research methods in constant expansion. ${ }^{1}$

Archaeology therefore plays a determining role in the protection of the cultural heritage, as well as in any project geared towards the transformation of the territory. Its contribution to the interpretation and understanding of the soil and subsoil cannot be neglected. In spite of all this, the discipline is to a great extent isolated in Italy today. The theoretical debate takes place solely in academic circles, and its role in the protection of the territory is virtually limited to the application of the restrictions laid down by law. Substantially excluded from planning operations, it plays only a modest part in decision-making processes. The peripheral nature of its sphere of action and its insufficiently active presence in Italian society are partly the result of the history of Italian archaeological studies, and partly due to a certain vagueness in the definition of the purpose of archaeological investigations. This has a negative effect on the legislation concerning the cultural heritage, which dates back to the late 1930s and is in urgent need of modernization. The cultural heritage is seen by the law, and in the attitudes of the general public, essentially as monuments visible at surface level. In the laws for the protection of this heritage, its connection with the environment and the landscape is merely generic, as if people, nature and culture were three separate entities. In addition, there is no awareness of the subsoil as a historic reservoir of fossilized landscapes, invisible but not for this reason non-existent. We therefore require a new reflection on the very meaning of the cultural heritage.

In the following pages, I shall attempt to provide this by way of a critical analysis of a number of Italian laws on the cultural heritage and environment. My aim is to arrive at a more widespread and dynamic definition of the cultural heritage than currently exists, that takes into account the continuous transformations of the territory and the human environment (the interaction between human beings and the environment) seen as an inseparable unit.

\section{SOIL AND SUBSOIL}

The close bond between soil and subsoil, and the importance of these as sources for the historic reconstruction of our past, has been an obvious fact since the time when archaeology was first put forward as the science of stratification, shaking off its traditional historic-artistic image. The significance of the subsoil as a 'fossilized narrative' is something we have considered on other occasions (Negroni and Domanico 1997, 1998). What I wish to point out in this study is that, as far as the Italian 
legislation is concerned, the subsoil in this sense does not even exist. It does not appear in the law for the protection of the cultural heritage (law 1089/1939), which I shall examine below. This aims merely at safeguarding the heritage as things ('cose'), in other words the objects and monuments of note visible on the soil (articles 1 and 2). Nor is there any reference to the 'subsurface' in the various laws regarding the environment. The initial idea of the environmental heritage (bene ambientale) as an object of 'natural beauty' to be contemplated and protected essentially for its aesthetic value (law 778/1922 and law 1497/1939) - which we can therefore compare with the 'objects of artistic and historic interest' referred to in law 1089 - therefore has no space for the subsoil, which is considered merely as the world of geological strata and underground waters, and is described as such in the presidential decree (DPCM) of 27 December 1988 concerning the regulations for the assessment of environmental impact. Point 2a of Appendix I to this decree defines the soil and the subsoil together in terms of geology, geomorphology and soil science 'nel quadro dell'ambiente ... ma anche come risorse non rinnovabili' ('... within the context of the environment . . . but also as non-renewable resources'). In Appendix II point $C$, these elements are referred to in greater detail, but human activities are considered only in terms of their effects on the geomorphological structure of the subsoil. In spite of the highly analytical attention paid by this decree to the territory, the subsoil is not taken into consideration in terms of its relationship with the landscape or its historic significance. It also remains unacknowledged in later laws concerning the environmental heritage, in spite of the introduction of a number of important innovations, such as law no. 183 of 1989 and no. 341 of 1991. And yet, in the list of objects that form part of the heritage of the state and the provincial and local authorities, the civil code (in book III, article 826) also includes '... le cose di interesse storico, archeologico, paletnologico, paleontologico e artistico da chiunque e in qualunque modo ritrovate nel sottosuolo . .' ('. . . objects of historic, archaeological, paleo-ethnological and artistic interest, and any others situated in the subsoil ...').

\section{ENVIRONMENT, TERRITORY, LANDSCAPE}

In the 1970s and, above all, the 1980s, a major debate developed in Italy on the definition of environment, territory and landscape. This was to a certain extent stimulated by the increasing public sensitivity towards environmental problems. One consequence of this was a general re-think on the value and significance of these concepts, but this was accompanied by a proliferation of differing definitions and approaches. The Italian legislation appears to have taken note of the new sensitivity and the positive nature of the theoretical debate, but it has also picked up the resulting confusion and terminological uncertainty. Consequently, the way in which the law deals in practice with the defence, conservation or evaluation of the heritage is not always clear. In particular, there is a certain ambiguity in the general definition of the territory as a space in which a community lives and interacts with its 
surroundings. In this sense, the territory becomes a simple container of physical objects which can therefore be manipulated and transformed. This is a reductive approach which tends to see the territory as a neutral, objective background, and brings in its wake the idea of an immobile landscape, also made up of 'things' (monuments, traces left behind by human communities, objects of 'natural beauty') which form the visual representation of the world that surrounds us. It has already been suggested that to consider the territory as a space leads us to highlight its functional aspects only. In this way, the notion of territory as culture is replaced by that of a space complete with fittings (Sereno 1981). This view finds its theoretical justification in the conviction that the natural and human environments are two separate entities and that, in our western societies at least, the intervention of man is so radical as to have led to the total humanization of the territory/landscape, which can therefore be remodelled ad infinitum. In this way, the conflict between conservation and transformation becomes even more dramatic. The reaction to this view by geographers sensitive to the cultural aspects of the territory is to eliminate the term 'space' and use 'territory' alone (Cori 1975), to the point where the existence of the landscape is denied, as this is too rich in meaning to be usable in planning, and is therefore replaced with a global notion of the enviromment which includes its natural aspects and those constructed and used by people (Zunica 1994).

The first Italian law on the protection of the environment dates from the $1920 \mathrm{~s}^{2}$ when the concept of 'natural beauty' (bellezza naturale) was introduced. The argument was later taken up by law no. 1497 of 1939 , which is still in force today. When this law was approved at the end of the 1930s, the modern idea of the environmental heritage as a global heritage still did not exist. The conception of the environmental and artistic heritage as isolated objects of natural beauty to be contemplated as spectacular and unique ${ }^{3}$ was linked to an idealistic, romantic philosophy that emphasized the aesthetic and artistic aspects of the landscape, in an exceptionally élitist and academic way. Law no. 1497 took into consideration panoramas and immovable objects, such as buildings and monuments. However, we can identify three elements of interest: (1) the need to create a 'territorial landscape plan' ('piano territoriale paesistico' - article 5); (2) the idea of an 'area of respect' (area di rispetto') around objects of beauty (article 11, which reflects the spirit of article 4 of the older law 778 of 1922); and (3) the concept of 'free enjoyment' ("ibero godimento') of objects of natural beauty (article 14).

The town planning law, which remains in force today, ${ }^{4}$ was approved in 1942 , and eloquently expresses the need for the global reorganization of the territory by means of local authority planning interventions (article 4) for the co-ordination of building operations (articles 4 and 5). Without clearly expressing its objectives, this law seems to implicitly accept the traditional ideas of space/territory that $I$ have described earlier, while remaining ambiguous in its general principles. It was only with the later modifications introduced by law $765 / 1967$ that mention began to be made of the 'tutela del paesaggio $e$ dei complessi storici, monumentali, ambientali e archeologici' 
('protection of the landscape and historic, monumental, environmental and archaeological complexes' - article 3, point c), giving the Ministry of Education, which had responsibility for the cultural heritage at that time, and the heritage bodies the possibility of expressing any comments they might have ('eventuali osservazioni' article 5). However, the vacuum of the 20 years that lapsed between the passing of the first law and its modifications enabled building speculators to make radical transformations of the Italian landscape. No mention is made of the conservation of the subsoil. ${ }^{5}$ In article 1, which was not replaced in the 1967 law, we read that the Ministry of Public Works 'vigila sull'attività urbanistica anche allo scopo di assicurare ... il rispetto dei caratteri tradizionali' ('supervises the town planning operations with a view to guaranteeing . . . respect for its traditional nature'), but the accent is firmly placed on the need for building renovation and expansion in the towns. Once again, then, we have the unresolved conflict between conservation and transformation. In practice, town-planning and building powers and those for the management of landscape conservation remain separate and have different objectives (Filippi 1994).

In the years that followed, many changes took place in the collective mentality. Particularly interesting, and closer to reality, is the idea that the territory and our perception of the landscape are defined subjectively, by means of the emotions, experience and intuition of the observer (Dematteis 1985; Colombo 1994; Zerbi 1994a). ${ }^{6}$ This is the most recent and innovative tendency, which attempts to reunite the concepts of territory, landscape and environment in a single notion of a setting not only experienced (living space) (Frémont 1978), but also perceived and imagined (Guérin 1985). ${ }^{7}$ Having overcome the traditional identification with only the physical elements of the human environment (geographical landscape), the landscape now becomes a synthesis of these and the cultural aspects, but there is also space here for the aesthetic and emotional context of the observer or the group that lives in the landscape. Awareness of the landscape is therefore not possible unless by means of an act of intuition. This is an extremely complex concept that eludes the restriction of a precise definition, and touches not only the entire cultural history of humankind and the environment in which people lived, but also that infinity of psychological nuances connected with their perception and imagination (the same landscape is regarded differently by those who live in it, its planners, people from different cultures, and so on) (Andreotti 1994:79; Renfrew and Bahn 1996:509). The global conception of the landscape as a synthesis recovers and binds together three elements: an ecological view; the traditional geographical notion of the landscape; and the cultural conception of landscape, as proposed by French geographers such as Sorre, Michotte and Fèbvre, as well as the aestheticsentimental and artistic vision of the German geographers and philosophers. This latter coincides with the mythical dimension of landscape, taken up in Italy in the philosophy of Benedetto Croce and others, such as von Humboldt, Ratzel and Cassirer. ${ }^{8}$ 
If; then, we accept this global definition of environment/territory/landscape, the problem of its safeguarding, conservation and transformation, which it is the task of the law to govern, is no longer simply a matter of organization and planning, but also takes on an ethical element. In addition, how is it possible within a synthesis of this kind to continue to regard the cultural heritage as a separate entity?

Recent Italian legislation on the environment has followed the various stages in the theoretical elaboration of these themes without reaching a satisfactory synthesis. In other words, there are no regulations that take into account the various aspects that make up the environment in which we live simultaneously and within the same context. The relationship between the legislative and executive bodies with regard to the territory and environment is not always clear, due mainly to the fragmentation and overlap of competence among the state, regional, provincial and local authorities which make up the constitutionally recognized administrative divisions of the republic (Part $\mathrm{II}_{,}$Heading $\mathrm{V}$ of the Italian Constitution). At least seven ministries have authority over the territory, ${ }^{9}$ with consequences on united action that we can easily imagine (Amorosino 1994; Bottini 1994; Cogliandro 1994; Caravita 1994b).

In this way, the good intentions of a number of laws came to nothing, for example, law 431/1985 for the protection of zones of environmental interest, law $349 / 1986$ for the setting up of the new Ministry of the Environment, the DPCM of 27 December 1988, which governs the regulations for environmental impact studies (as incorporation of the European Community directives of 27 June 1985), law 183/ 1989 on the reorganization and defence of the soil, and law 394/1991 on protected areas. ${ }^{10}$

Law no. 431, which converts the legislative decree (DL) $312 / 1985$, is a very important development in the Italian environmental legislation. The legislator himself is aware of this when, in article 2 , he writes, 'le disposizioni . . costituiscono norme fondamentali di riforma economico-sociale della Repubblica' ('the provisions . . . are fundamental regulations for the socio-economic reform of the Republic'). The term landscape, which is already present in the fundamental principles of the Constitution (article 9), ${ }^{11}$ appears, although the references are prevalently to its natural aspects (article 1, point a/1). Point $m$ mentions only the zones of archaeological interest. The aim of the law is protection by means of restrictions of the 'zone di particolare interesse ambientale' ('zones of special environmental interest'), but article 1 bis repeats the requirement that the regions put the landscape plans into action, as had already been laid down, but without any clear results, in law 1497/1939, with the Education Minister of the time entrusted with the application (article 5).

Both law 349/1986 and law 183 of 1989 had ambitious objectives. Law 349 aimed to 'assicurare, in un quadro organico, la promozione, la conservazione ed il recupero delle condizioni ambientali conformi agli interessi fondamentali della collettività $e$ alla qualità della vita, nonché la conservazione e la valorizzazione del patrimonio naturale nazionale $e$ la difesa delle risorse naturali dall'inquinamento' ('ensure, within an organic frame- 
work, the promotion, conservation and recovery of the environmental conditions in line with the fundamental interests of the community and the quality of life, as well as the conservation and due recognition of the natural heritage of the nation and the defence of its natural resources against pollution' - article 1.2). For this purpose, the Ministry of the Environment was created. Among its various functions, the Ministry has the task of promoting studies, distributing information and setting up initiatives to increase the public's awareness of environmental problems. As far as our analysis here is concerned, it is interesting to note the mention, for the first time, of the concept of 'the quality of life' and the informative (article 14.1) and educational (articles 1.2 and 5.2) aims of the law. With regard to the cultural heritage, however, we have to note that the Ministry for the Cultural Heritage takes action above all in situations which involve restrictions, even though it is able to express its opinions on 'environmental compatibility' ('compatibilità ambientale' - article 5.6), while the initiatives for the defence of the soil are taken together with the Ministry of Public Works (article 2.6). Caravita was very precise in his identification of the limits of this institution, which he saw as essentially an overlap of yet another ministerial structure of the traditional type upon the numerous administrative bodies that already dealt with the question of environmental protection. This has negative consequences for the practical management of the heritage. The merit was, however, in the identification of the environment as one of our prime interests, elevating it to a position of political dignity (Caravita 1994b).

Law no. 183 of 1989 deals with the protection of the soil from the hydrogeological viewpoint above all. Neither the subsoil nor the visible landscape are considered from the standpoint of the cultural heritage. In article 1.3, we find listed under the item 'soil' ('suolo') the territory, the soil, the subsoil, human settlements and the infrastructure. However, this law contains an important innovation. Article 2 speaks of the need for so-called 'activity of awareness' ('attività conoscitiva'), that is, the preliminary search, collection, processing, experimentation and assessment of data - an activity considered indispensable for the achievement of the aim of protection, as laid down by the law. Even though the concept remains somewhat generic, we may feel justified in thinking that the value of the subsoil, cultural heritage and landscape are granted the attention they deserve in this activity. Stefano Civitarese Matteucci has already expressed his opinion on the jurisprudential meaning of 'activity of awareness' in the pages of the Rivista Giuridica dell'Ambiente (Civitarese 1994). ${ }^{12}$ I wish to emphasize the following two elements: (1) for the first time, the practical need emerges to face the problem of the territory in a more organic way (even though the main attention is directed towards the instability of the hydro-geological situation) by means of the creation of national technical services ('Servizi tecnici nazionali') (article 9); (2) the fundamental principle of 'know to decide' ('conoscere per decidere') is affirmed.

This was a positive precedent for the laws that were to follow, for example law $394 / 1991$ on protected areas. The objectives proclaimed in law 394 appear to be the most coherent with our observations so far. In article 1 point 1 , we read, 
'La presente legge ... detta principi fondamentali per l'istituzione e la gestione delle aree naturali protette, al fine di garantire e di promuovere, in forma coordinata, la conservazione e la valorizzazione del patrimonio naturale del paese' ("This law . . . lays down the fundamental principles for the setting up and management of protected natural areas, with a view to guaranteeing and promoting the conservation and evaluation of the natural heritage of the country in a co-ordinated manner'). By the term 'natural heritage', the law refers not only to the geomorphological, biological and physical elements (article 1, point 2), but also to the anthropological, archaeological, historic and architectural factors, and the traditional forestry and pastoral activities considered as values (article 1, point $3 b$ ).

However, after this preamble, article 1 of the law 'forgets' the cultural heritage and excludes the specialists involved in evaluating and safeguarding it from the decisionmaking processes. Even though it includes, among others, the Ministry for the Cultural Heritage in the protected areas specified in article 3.1, it devotes no attention to the cultural heritage as an integral part of the heritage when it lists the responsibilities of this committee. In point 2 , we read "The Committee identifies the fundamental lines of the layout of the territory with reference to natural and environmental values ...' ('Il Comitato identifica . . . le linee fondamentali dell'assetto del territorio con riferimento ai valori naturali e ambientali ...'). Point 3 states, ' . . . it identifies the state of the natural environment in Italy, highlighting the natural values and the profiles of vulnerability of the territory' (". . individua lo stato dell'ambiente naturale in Italia, evidenziando $i$ valori naturali e i profili di vulnerabilità del territorio'), then goes on to classify the protected areas (point 4a), adopts the programme for these (point 4b) and approves the official list of them (point 4c). So where has the cultural heritage vanished to? Further on, when it sets up a Consultative Body to express technical and scientific opinions on the subject of natural protected areas (article 3, point 7), there is no clear indication that any of the nine experts appointed to take part in this should have responsibility for the cultural heritage. Finally, from an initial situation of lack of power over the territory, this law takes us to the opposite extreme, with excessively complex parks management procedures. The limits of this law are well analysed by B. Caravita, who brings to light a number of unconstitutional elements, especially with regard to the removal of power over the territory from the local authorities (Caravita 1994a).

In spite of this, the environmental debate of the 1980s is therefore beginning to bear fruit. We see the slow acceptance of the idea that natural and human elements, and consequently the environmental and the cultural heritage, have to be considered together. Circular 8 of 31 August 1985, issued by the Minister for the Cultural Heritage, did not pass unobserved, when it drew attention to this unity by including in the 'landscape and environmental heritage' the 'archaeological, architectural, historic and artistic' heritage. Nor did the letter to the presidents of the regional authorities sent out the following year by the same minister, in which he repeated and developed this concept ${ }_{r}^{13}$ or sentence 151 of 1986 by the 
Constitutional Court, which defined the landscape/environment as a value of 'super-primary' interest ('interesse superprimario').

What is still missing is the concrete presence of the problem of the cultural heritage in the critical stage of the decision-making process. The cultural aspect may be the subject of the preliminary studies and now virtually always appears in the declarations of principle and the objectives of the laws on the environment of recent years, but what effective powers over the territory are held by the Minister for the Cultural Heritage?

\section{Cultural heritage}

The Italian national law for the protection of the cultural heritage was approved in 1939, and took up the fundamental principles that had been expressed in the previous laws of the earlier Italian states, in particular those of the Kingdom of the Two Sicilies (Regno delle Due Sicilie) and the Pontifical State (Stato della Chiesa). Each of these states, concerned over the progressive loss of the works of art in its possession, adopted restrictive laws against the export, sale and theft of its artistic heritage from the fifteenth century onwards, with particular reference to paintings and Greek and Roman marbles. In Rome, in spite of the countless violations that led to the sale of works of art and archaeological finds to foreign collectors, the English and French especially, and the despoilation of several ancient monuments, such as the Colosseum, the restrictions applied by the various Popes succeeded in preserving most of the works, which were seen as properties inherited from the past. $^{14}$. The history of these restrictions and the alternating sequences of events that led first to the conservation, then to the loss, and so on, of the cultural heritage have been described by several scholars on various occasions (Emiliani 1978, 1979; Haskell 1981), and we need not examine them in detail here. What is interesting for our analysis are the steps taken by Popes Clement XII (1730-40), Clement XIV $(1769-74)$ and Pius VI (1775-99). Here, for the first time, the concept of works of art that cannot be given up is expressed, and the solution to the problem of their conservation is provided by the setting up of the first public museums (The Capitoline Museum ${ }^{15}$ and the Museum of Pius-Clement in the Vatican). At the same time, the Popes ensured their control over the objects discovered in the new archaeological excavations, just as in Naples extremely strict control was exerted over the excavations of Herculaneum and Pompeii by the Bourbon rulers (Pietrangeli 1958; Haskell 1981). The conception of the cultural heritage as the permanent property of the state, and consequently of the public, takes this beyond the status of a mere collection of goods and takes us up to the present day by way of a number of important provisions, such as the decree issued by Pope Pius VII in 1802 (which, among other things, appointed the sculptor Antonio Canova 'inspector for the arts'), the edict proclaimed in 1820 by Cardinal $\mathrm{Pacca}^{16}$ and the law of 1902 , which for the first time made an attempt at uniting the previous provisions and can be considered as the first national law of the united state of Italy on this 
matter. One of the problems identified in all these measures as among the most urgent was the classification of works of art and archaeological finds in public and private collections. The reluctance to give up what were seen as the sacred rights to private property and the ignorance of the real extent of the heritage continued to lead to the progressive loss of many ancient objects. One emblematic example is the incredible sale of the private collection of Marquis Giampietro Campana (containing thousands of archaeological finds, paintings by Botticelli and Paolo Uccello and a series of frescoes attributed to Raphael), defying all the laws against it, by Pope Pius IX in 1857 (Haskell 1981:28-29). The drafting of the famous list of the items belonging to the cultural heritage remained a preoccupation at the start of the twentieth century and remains partially unresolved even today. In any event, the law of $1939^{17}$ that constrains the provincial and local authorities to present a list of its public heritage (article 4 ) is much less drastic as far as the ecclesiastical heritage is concerned (article 8), while the obligation for private individuals concerns only those objects listed (notificati) by the Ministry (article 9). These are the ' ... cose ... che . . . siano state riconosciute di interesse particolarmente importante' ( $\ldots$ objects . . . that ... have been recognized as being of particularly significant interest' ${ }^{\prime}$-article 2) - a generic and dangerously subjective definition. The new element introduced by this law is, however, the important statement of the right to the 'uso e al pubblico godimento' ('public use and enjoyment') of the objects (article 7) and the introduction of the concept of protection in the very heading of the law itself. However, the heritage in question is considered as 'things', objects whose contextual value is not taken into consideration, while the general spirit of the law, as we have seen, takes its inspiration from the aesthetic 'beauty' that makes the object worthy of respect and admiration.

In recent years, the cultural heritage has been significantly enriched by the debate surrounding it. The cultural heritage is seen today as an integral part of our lives, cultural tradition and surroundings (Bossaglia 1978; Emiliani 1979, 1990). As with the landscape, the cultural heritage too has become a global concept in which subjective emotion plays an important role. The tendency of the law to emphasize only the capital value (economic and jurisprudential) implicit in the term 'object' is therefore highly reductive. In addition, the law deals with the problem of protection only from the point of view of conservation, with the imposition of sanctions and restrictions. It should therefore come as no surprise that the cultural heritage appears in the legislation on the environment almost exclusively when it presents a risk, in other words, when a project on the territory is 'limited' by the presence of an archaeological restriction and the intervention by the Ministry for the Cultural Heritage consists merely in ensuring observance of this, or at the most the 'expression of opinions'. And yet, the problem had already been considered in global terms by the so-called Franceschini Commission, set up in 1964 with a view to analysing the situation of the cultural heritage in Italy. ${ }^{18}$ In 1967, the commission published its final report of around 3000 pages, eloquently entitled 'Per la salvezza dei beni culturali in Italia' ('For the salvation of the cultural heritage in Italy'). Even though this 
continued to use the term 'thing' as in law 1089, the modern concept of cultural heritage as an integral part of society, history and the landscape is introduced. The fate to which this report was destined is something I have described elsewhere (Negroni and Domanico 1998). The study was to have been followed up by the project for a new law on the cultural heritage, but this was never accomplished.

The global definition of cultural and environmental heritage still does not contain the value of the subsoil as we have attempted to define it in the preceding pages. The role of archaeology in helping us to understand this would be a determining one. But what is remarkable is the total lack of commitment by Italian archaeologists to the theoretical debate on the cultural heritage. When they do make their voices heard, it is usually with a view to considering the problem from the bureaucratic and administrative viewpoint (Cerulli 1980), in terms of protection (Guzzo 199192), to engage in disputes over the problems of conservation or export of works (Torelli 1992), or to criticize the inefficiency of the state institutions (Carandini 1979). It would appear that, up to now, only the geographers (Gambi 1984; Dematteis 1985; Colombo 1994; Fedel 1994; Zerbi 1994b), the legal experts and the environmentalists (Benini 1993; Scavone 1993; Caravita 1994b and 1994c) have developed an elaborated and modern idea of the significance of the cultural and environmental heritage.

\section{Conclusions}

In this study, we have attempted, by means of an analysis of the most important Italian laws on the cultural and environmental heritage, to point out how the theoretical approach to the problems of the territory and cultural heritage has developed in the course of time, and the factors that still remain unresolved today in terms of its protection and evaluation.

There is a gradual appreciation, in the law, of the most innovative elements in the debate on these matters, especially the notion of the environment and human history as a global, unified entity. However, in practical terms, no satisfactory solution to the problem of conservation within the context of the inevitable transformations taking place around us has been found.

One of the main reasons for this is probably the lack of co-ordination among the various bodies that have responsibility for taking the decisions. However, there is also a certain slowness in understanding the meaning of what we could define as the human environment. In spite of the interesting nature of many of its notions, the theoretical debate has difficulty in overcoming the élitist limits of an area set aside exclusively for the specialists. In other words, it fails to penetrate Italian society in depth. But the comprehension of these problems is first and foremost a cultural factor, and has to do with the subjective and emotional experience of each one of us. The recovery of this cultural and psychological dimension seems to me to be one of the most interesting potential contributions to the current debate. 
We have also attempted to examine what contribution archaeology could make to this debate. Without doubt, one of the most important aspects is the understanding that, alongside the visible dimension (the landscape that surrounds us), there is also an invisible landscape hidden beneath the soil, whose value as a historic reservoir and testimony to the past cannot be underestimated. The awareness that the continuous transformations that take place in the course of time leave their mark on the soil and subsoil and that both contribute to the formation of the complete landscape in which we live is undoubtedly one of the most stimulating elements for future research. At the present time, archaeology appears to be the only discipline that can comprehend this value of the subsoil and supply the tools we need to interpret it.

Each loaded with a multiplicity of meanings, concepts such as environment, territory, landscape, soil, subsoil and cultural heritage become incomprehensible if they are considered in isolation. Their reciprocal and constant interaction also produces continuous transformations and innovations. We are therefore not dealing with a static reality that we can only lock up or protect in a museum, delegating its protection to the articles of the law. Our understanding of these notions is, as we have said, a matter of culture, but also and especially a question of intuition, an emotional experience. The landscape may be invisible, but it still exists. The statement of this unity is a challenge to the mono-cultural thinking of our western societies, and as such has a non-conformist and subversive power. However, it is in the complete perception of the human environment as a global universe, a space that we live in, perceive and imagine in continuous transformation and interaction, that we not only complete the definition of the cultural heritage, but at the same time identify the possibility of thinking of a new planning approach that may not resolve but will at least reconcile the conflict between conservation and transformation. The acceptance of this complexity and the ability to deal with it is the great cultural challenge of the years to come.

\section{ACKNOWLEDGEMENTS}

This article takes up, develops and expands on arguments we have already dealt with in a number of lectures delivered during the specialist courses in 'Communications for the Cultural Heritage' and 'The Restoration of Monuments' at the Polytechnic of Milan between 1992 and 1995, and in the course dedicated to problems of archaeology and environmental impact we organized in 1992 at the Department of Earth Sciences of the Polytechnic of Milan. The same argument was presented on. the occasion of the international seminar on II Sistema Uomo - Ambiente tra Passato e Presente' at the European University Centre for the Cultural Heritage of Ravello, held in June 1994, and during the XIII UISPP Congress, 1996 (workshop 10) and the third EAA Annual Meeting of Ravenna, 1997 (Session II.1). For their comments and observations on those occasions, we wish to thank Claude Arbore Livadie, organizer of the Ravello conference, Adriana Martini, co-ordinator of 
workshop 10, John Carman, organizer and chairman of session II.1, and our colleagues who were present at these events. I also wish to thank my sister, M. Grazia Domanico, magistrate in Milan, for her comments on the legislative aspects of the study. I am very grateful to Colin Wood for the English translation and to the two anonymous referees.

\section{Notes}

1. 'Archaeology today is a global discipline, and its research methods have a universal application.' (Renfrew and Bahn 1996:9). Perhaps an excessively optimistic statement, but we tend to agree.

2. Law 778 of 1922 published in the Gazzetta Ufficiale (GU - Official Journal) no. 148 of 24 June 1922.

3. GU no. 241 of 14 October 1939. This intention is also explicitly declared in article 1, which states that the protective restriction applies only to the things and monuments that stand out for their uncommon beauty ('Sono soggette alla presenete legge a causa del notevole interesse pubblico le cose immobili che hanno ... caratteri di bellezza naturale o di singolarità geologica; le ville, i giardini e i parchi che . . . si distinguono per la loro non comune bellezza; . . . cose immobili che hanno valore estetico e tradizionale; le bellezze panoramiche considerate come quadri naturali e così pure quei punti di vista o di belvedere ... dai quali si goda lo spettacolo di quelle bellezze $)$. This concept derives from the previous laws on phenomena of outstanding natural beauty - no. 364 of 1909 and no. 778 of 1922.

4. Law 1150 of 17 August 1942, published in GU no. 244 of 16 October 1942. A number of modifications were introduced with law 1357/1955, law 765/1967 and ministerial decree (DM) 1444/1968.

5. It is interesting to note that most archaeological discoveries in Italy take place during excavations carried out prior to building work.

6. The value of subjectivity in the perception and interpretation of our past, as a result of which it is inevitable to proceed by way of successive approximations, is also expressed in the most recent trends in theoretical archaeology. (Hodder 1991).

7. Living space refers to the cultural dimension and social groups, for example in their sense of belonging. The space perceived is the way in which this is interpreted and the meanings attributed to it by those who live in it or speak of it. Finally, the space imagined is the mental framework formed, for example, by the decision makers, politicians, town planners and those whose interests are directed towards the territory (Tommasini 1994).

8. For an analysis of the trends in the German school with regard to the landscape, see Andreotti 1994:77-80 and bibliography.

9. Ministries of Public Works, the Environment, the Cultural and Environmental Heritage, Health, Industry, Departments of the Urban Areas and Civil Protection (Amorosino 1994:594).

10. Law 431/1985: GU no. 197 of 22 August 1985 and GU no. 218 of 16 September 1985; law 349/1986: GU no: 162 of 15 July 1986; DPCM of 27 December 1988: GU no. 4 of 5 January 1989; law 183/1989: GU no. 120 of 25 May 1989; law 394/1991: GU no. 292 of 13 December 1991.

11. Constitution of the Republic of Italy, 25 April 1945. Fundamental principles, article 9: "The Republic promotes the development of culture and scientific and technical research. It safeguards the landscape and historic and artistic heritage of the nation' ('La Repubblica promuove lo sviluppo della cultura e la ricerca scientifica e tecnica. Tutela il paesaggio e il patrimonio storico e artistico della Nazione'). 
12. The importance of the activity of awareness that precedes an administrative act had already been emphasized by the Franceschini Commission in its 1967 report, referred to later in this paper.

13. This letter clarified the spirit in which law no. $431 / 1985$ was drafted, and invited the presidents of the local authorities to take part in a meeting to discuss the problems that emerged in the application of this law, which was completely innovative at the time.

14. See for example the measures against exports issued in 1686 by Pope Innocent XI after Louis XIV had succeeded in buying the two famous sculptures of Germanicus and the so-called Cincinnatus (Haskell 1981:11-12).

15. The original nucleus of the museum had already been formed as a result of the donation made to the people of Rome in 1471 by Pope Sistus IV of a number of bronzes from his private collection.

16. The edict issued by Camerlengo Cardinal Bartolomeo Pacca is one of the most important legislative acts of the Pontifical State. Issued in 1820 on the basis of the equally important decree by Pope Pius VII of 1802 (known as the 'Chirografo Chiaramontiano'), the edict defines and lists in even greater detail - in 61 articles - the objects to be safeguarded, lays down the tools to be used to defend the heritage and the penalties for transgressors and those who fail to comply. One of the most innovative provisions of the edict is the decentralization of the safeguarding bodies, with the creation in the Provincie dei Pontificj Dominj" of a series of Auxiliary Commissions (Commissioni Ausiliarie) to the General Consultative Committee for the Antiquities and Fine Arts (Commissione Generale Consultiva di Antichità e Belle Arti) established in Rome (article 5). For a detailed analysis of this edict and the role of the Commissions, see Brizzolara 1984 and bibliography. For the decree by Pius VII, see Haskell 1981:27-28.

17. Law 1089/1939 'Tutela delle cose d'interesse artistico e storico', GU no. 184 of 8 August 1939. This law updated and replaced law 364/1909, but without repealing it.

18. Law 310/1964, GU no. 128 of 26 May 1964.

\section{REFERENCES}

AMOROSINO, SANDRO, 1994. La riforma dei Ministeri dell'ambiente e dei lavori pubblici e la riorganizzazione delle funzioni statali in tema di territorio-paesaggioambiente. Rivista Giuridica dell'Ambiente 5:593-600.

ANDREOTTL, GIULIANA, 1994. La geografia culturale e il tema del paesaggio. In M. C. Zerbi (ed.), Il paesaggio tra ricerca e progetto: 63-85. Torino: G. Giappichelli Editore.

BENINI, S., 1993. Beni culturali e interessi diffusi. Foro Italiano III:100.

Bossaglia, Rossana, 1978. Crisi del patrimonio artistico italiano. Architettura e complessi ambientali. In La difesa del patrimonio artistico: 41-59. Milan: Arnoldo Mondadori.

BOTIINI, MARINO, 1994. Evoluzione della normativa in tema di controlli ambientali. Rivista Giuridica dell'Ambiente 6:776-794.

Brizzolara, ANNA MaRIA, 1984. La Commissione Ausiliaria di Antichità e Belle Arti (1820-1859). In C. Morigi Govi and G. Sassatelli (eds), Dalla Stanza delle Antichità al Museo Civico: 177-185. Bologna: Grafis Edizioni.

CARANDINI, A., 1979. Archeologia e cultura materiale. II. Per $i$ 'beni culturali': 163-237. Bari:De Donato.

CARAVTta, BEnIAMINo, 1994a. Potenzialità e limiti della recente legge sulle aree protette. Rivista Giuridica dell'Ambiente 1:1-11. 
Caravita, Beniamino, 1994b. Stato, regioni ed enti locali nelle politiche di gestione dell'ambiente: i problemi del raccordo di competenze. Rivista Giuridica dell'Ambiente 3/4:360-380.

Caravita, Beniamino, 1994c. La bozza di disegno di legge generale in materia ambientale. Rivista Giuridica dell'Ambiente 3/4:525-552.

Certuli IRELLi, MARIA GIUSEPPINA, 1980. La disciplina legislativa delle ricerche archeologiche. In Atti del I Convegno Archeologico Regionale: 29 February-12 March 1980. Milan.

CivitaRese MATTEuCCI, STEFANO, 1994. Difesa del suolo e attività conoscitiva della Pubblica Amministrazione. Rizista Giuridica dell'Ambiente 2:185-202.

COGLIANDRO, GIUSEPPE, 1994. La protezione dell'ambiente in Italia. Rivista Giuridica dell'ambiente 2:169-183.

COLOMBO, ROBERTO, 1994. Approccio qualitativo e quantitativo all'analisi del paesaggio. In M. C. Zerbi (ed.), Il paesaggio tra ricerca e progetto: 187-210. Turin: G. Giapichelli.

CORI, BERARDO, 1975. L'organizzazione del territorio e il ruolo della geografia. Cultura e scuola XIV (53):111-119.

DEMATTEIS, GIUSEPPE, 1985. Le metafore della terra. La geografia umana tra mito e scienza. Milan: Feltrinelli.

EMILIANI, ANDREA, 1978. Leggi, bandi e provvedimenti per la tutela dei beni artistici $e$ culturali negli antichi stati italiani, 1571-1860. Bologna: Alfa Editoriale.

EMILIANI, ANDREA, 1979. I materiali e le istituzioni. In G. Previtali (ed.), Storia dell'arte italiana, Parte I, vol. I: 99-161. Turin: Giulio Einaudi.

EMILIANI, ANDREA, 1990. Bene culturale non è una merce. In P. G. Guzzo, A. Emiliani and M. E. Vesci (eds), Profili della Daunia antica, 6 Ciclo di conferenze sulle più recenti campagne di scavo: 20-24. Foggia: Soprintendenza Archeologica della Puglia.

FEDEL, PAOLO, 1994. Dalla tutela del paesaggio alla tutela paesaggistico-ambientale. In M. C. Zerbi (ed.), Il paesaggio tra ricerca e progetto: 211-223. Turin: G. Giapichelli.

FILIPPI, MADDALENA, 1994. Note sulla subdelega dalle Regioni agli Enti locali in tema di bellezze naturali. Rivista Giuridica dell'Ambiente 2:221-227.

FikÉMONT, ARMAND, 1978. La région, espace vécu. Milan: Franco Angeli editore.

GAMBI, LuCIO, 1984. Geografia fisica e geografia umana di fronte ai concetti di valore. In A. Celant and A. Vallega (eds), Il pensiero geografico in Italia: 105-130. Milan: Franco Angeli.

Gú́RIN, JEAN PAUl, 1985. Introduction. In J. P. Guérin and H. Gumuchian (eds), Les Représentations en Actes, Actes du Colloque de Lescheraines: 5-10. Grenoble: Institut de Géographie Alpine.

GUzzo, PIER GrovanNi, 1991-92. Alcune riflessioni sulle prospettive della tutela archeologica in Italia. Studi e documenti di archeologia VII (Soprintendenza Archeologica per 1'Emilia Romagna): 207-210.

HASKELL, FrANCIS, 1981. La dispersione e la conservazione del patrimonio artistico. In F. Zeri (ed.), Storia dell'arte italiana, Parte III, vol. III: 5-35. Turin: Guilio Einaudi editore.

HodDER, IAN, 1991. Reading the Past. Current Approaches to Interpretation in Archaeology. Cambridge: Cambridge University Press.

Negroni Catacchio Nuccia and LauRa Domanico, 1997. The invisible landscape. History of the subsoil, stratigraphic archaeology and environmental impact. Third Annual Meeting European Association of Archaeologists, Ravenna (I), 24/28 September 1997, Abstracts: 186. 
Negroni Catacchio Nuccia and laura Domanico, 1998. Territorio e cultura. Analisi del concetto di suolo e sottosuolo nel sistema legislativo italiano sui beni culturali e l'ambiente. XIIIth Congress of the International Union of Prehistoric and Protohistoric Sciences (UISPP), Workshop 10, 6(1):619-624. Forli: ABACO Edizioni.

Pietrangel, C., 1958. Scavi e scoperte di antichità sotto il pontificato di Pio VI. Rome. Renrrew, Colin and Paul BaHn, 1996. Archaeology. Theories, Methods and Practice. London: Thames and Hudson.

SCAVONE, A., 1993. Tutela archeologica, vincoli paesistici e pianificazione urbanistica. Rivista Giuridica Edilizia II:221.

SERENO, PAOLA, 1981. L'archeologia del paesaggio agrario: una nuova frontiera di ricerca. In L. Gambi (ed.), Campagna $e$ industria. I segni del lavoro: 24-47. Milan: Touring Club Italiano.

TOMMASINI, DANIELA, 1994. La costruzione dell'immagine turistica dell'Alto AdigeSüdtirol. In M. C. Zerbi (ed.), Il paesaggio tra ricerca e progetto: 123-146. Turin: G. Giapichelli.

TORELl, MARIO, 1992. Appunti sulla legge Covatta. Ostraka. Rivista di Antichità 1:157159.

ZERBI, MARIA CHIARA, 1994a. Il paesaggio tra ricerca e progetto: un'introduzione. In M. C. Zerbi (ed.), Il paesaggio tra ricerca e progetto: 3-34. Turin: G. Giapichelli.

ZERBI, MARIA CHIARA, 1994b. Il paesaggio nella valutazione di impatto ambientale. In M. C. Zerbi (ed.), Il paesaggio tra ricerca e progetto: 167-186. Turin: G. Giapichelli.

ZuNICA, MARCELLO, 1994. Dal mito del paesaggio al pragmatismo dell'ambiente. In M. C. Zerbi (ed.), Il paesaggio tra ricerca e progetto: 149-165. Turin: G. Giapichelli.

\section{BIOGRAPHICAL NOTE}

Laura Domanico, graduate of the University of Milan, finished a postgraduate course in prehistory and protohistory at the University of Rome and is currently completing a doctorate in European protohistory at the École Pratique des Hautes Études, Sorbonne, Paris. A specialist in the Bronze Age, she has taken part in, conducted and acted as scientific director in various excavations in Italy, Spain and France. She is involved in continuing research projects directed by the Department of Archaeology of the University of Milan for the study of southern Etruria during the Bronze Age, and a project on Alpine trade and cultural identity in later prehistory run by the French CNRS. She is a member of the Istituto Italiano di Preistoria e Protostoria and is the author of many scientific publications on these subjects and the problems surrounding Italian legislation on the cultural heritage.

Address: Garrel Farm, Balfron, Glasgow G63 0SQ, Scotland [email: CStrut@aol.com] 


\section{Abstracts \\ Il paesaggio invisibile. Sottosuolo, ambiente e legislazione italiana sui beni culturali e l'ambiente}

\section{Laura Domanico}

Nello studio viene esaminato l'apparato legislativo italiano sui beni culturali e sull'ambiente evidenziandone i ritardi sul problema della gestione dei beni culturali sul territorio e le lacune nella loro definizione e comprensione. Mentre il dibattito teorico in materia ambientale in Italia ha ricevuto un forte impulso negli ultimi anni, i beni culturali sono ancora regolati da leggi in gran parte superate ed essenzialmente di natura vincolistica e 'punitiva'. Materia ambientale e beni culturali vengono inoltre concepiti nell'apparato legislativo italiano come due ambiti ancora troppo separati, con gravi conseguenze sul piano della tutela, della salvaguardia e della valorizzazione del patrimonio. Viene quindi qui proposta una visione unitaria e dinamica del sistema uomo-ambiente che comprende sia il paesaggio visibile che quello invisibile, ma non per questo inesistente, nascosto nel sottosuolo. Si propone infatti una concezione del sottosuolo come un universo strutturato per la cui comprensione e interpretazione l'archeologia gioca un ruolo determinante. Prendendo in considerazione e quindi sottoponendo a norme di tutela e salvaguardia, solo ciò che 'si vede', cioè il paesaggio - ambientale e storico - di superficie, la legge dimentica che questo non è altro che il prodotto della serie di paesaggi fossilizzati e stratificati nel tempo. Cercando una nuova definizione del sistema uomo-ambiente, se ne propone una concezione che tenga conto delle continue trasformazioni e che non rinuncia ad un approccio anche intuitivo ed emotivo.

\section{Le paysage invisible. Sous-sol, environnement et législation italienne pour les biens culturels et 1'environnement}

Laura Domanico

Cette étude prend en considération la législation italienne sur les biens culturels et l'environnement en soulignant le retard dans la compréhension de ces problèmes et le manque d'une action cohérente en ce qui concerne leur gestion sur le territoire. Le débat théorique sur l'environnement a été fort développé pendant les derniers années, tandis que les biens culturels sont encore réglés par des vieilles lois avec un régime de contrôle et de 'punition' aujourd'hui dépassé. Territoire, paysage, environnement et culture sont encore considérés de façon individuelle, voire distincte, avec des graves conséquences pour la satuvegarde du patrimoine. On propose donc dans cette étude une idée unitaire et dynamique du système homme-environnement qui prend en considération soit le paysage visible, soit celui invisible, mais non pour cela pas existant, qui est dans le sous-sol. Le sous-sol lui-même doit en effet être conçu comme un univers structuré, le rôle de l'archéologie étant fondamental pour sa compréhension. En considérant uniquement ce qui on peut voir en surface, les lois oublient qu'il s'agit de rien d'autre que d'une synthèse des séries des paysages fossiles stratifiés dans le temps, dont une définition complète doit tenir compte d'une approche intuitive et émotive aussi. 